\title{
下顎骨骨折患者の治療前後における下顎頭の位置関係
} Schüller 氏変法撮影による検討——

\author{
平野裕士・竹之下康治・樺 山哲 郎*・岡 增一郎 \\ 田代英雄*
}

\section{An observation on the fracture of the mandible in pre-. and post-treatment with TMJ radiographs by modified Schüller's projection}

\author{
Hiroshi Hirano - Yasuharu Takenoshita - Tetsuro Kabayama* \\ Masuichiro OKA - Hideo TASHIRO*
}

\begin{abstract}
In cases of mandibular fracture, there are many variations in the condylar position in glenoid fossa. However, most show practically no functional disturbances in jaw movements. So the authors studied the relation between the radiological condylar position and clinical features.

The objects were 87 patients seen at the Department of Oral Surgery, Kyushu University Dental Hospital, between 1978 and 1983, and had taken in pre-. and post-treatment temporomandibular joint radiographs by modified Schüller's projection.

The results were as follows:

The condylar position in pre-. and post-treatment showed many variations, but we couldn't find a characteristic change in the condylar position at mouth close after treatment. The relation between functional disturbances and the condylar position were still not clarified. In our estimation after treatment, the jaw function seemed to be good in most cases because the condyles were situated at the anterior to the articular tubercle in the opening position. These results showed that the functional adaptation of the TMJ came about post operatively.
\end{abstract}

Key words: condylar position, mandibular fracture, radiology

緒

\section{言}

下顎骨骨折の治療では，非観血的あるいは観血的処置

九州大学崡学部口腔外科学第 2 講座

(主任：岡 增一郎教授)

* 九州大学菌学部口腔外科学第 1 諢座

（主任：田代英雄教授）

Second Department of Oral Surgery, Faculty of Dentistry, Kyushu University (Chief: Prof. Masuichiro Oka)

* First Department of Oral Surgery, Faculty of Dentistry, Kyushu University (Chief: Prof. Hideo Tashiro)

受付日：昭和 62 年 3 月 2 日
により，咬合，㴿運動機能の回復が図られるが，下㴿の 機能的変化については臨床的に㴿運動時の偏位, 開口の 制限, さらには下靧頭の位置変化などとしてみることが できる。

一方, 関節窩における下顎頭の位置と, 顎機能異常の つつである㴿関節症との間に深い関保があるとするとの 報告もある ${ }^{1 \sim 3)}$ ところが，下顎骨骨折症例では両者の 位置関倸に多様性がみられるにもかかわらず, 顎運動の 機能に障害を及ぼさない症例も多くみられる。下䋶頭の 位置およびその動きの観察には，主として Schüller 氏 変法撮影のX線像が用いられている。

今回, 著者らは下顎骨骨折患者の治療前後に拈汁る下 買頭の位置的変化をSchüller 氏変法撮影を用いて検討 し，若干の知見を得たので報告する。 


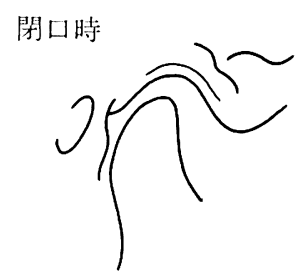

後方位 $(-)$

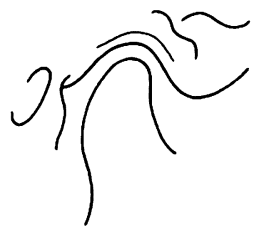

中央位 $(0)$

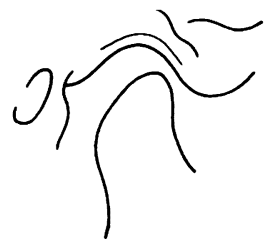

前方位 $(+)$

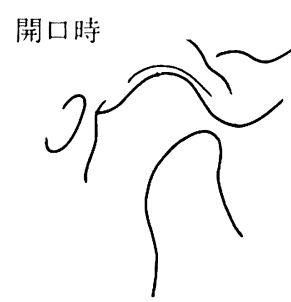

後方位 $(-)$

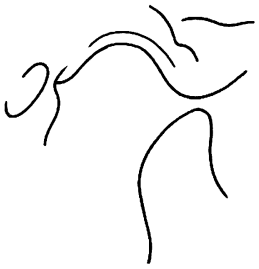

中央位 $(0)$

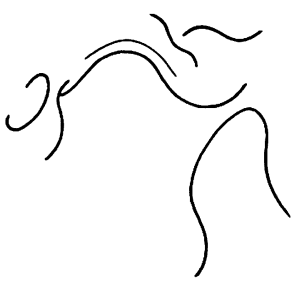

前方位 $(+)$

図 1 下顎頭の開・閉口時の位置の分類

表 1 骨体部骨折例の下靧頭の治療前後における位 置 (側)

\begin{tabular}{c|r|r|r|r} 
閉口洔 & \multicolumn{3}{|c}{ 側 } \\
\hline 前 & - & 0 & + & 後 \\
\hline- & 2 & 2 & 1 & 5 \\
0 & 3 & 15 & 2 & 20 \\
+ & 1 & 5 & 2 & 8 \\
\hline 計 & 6 & 22 & 5 & 33
\end{tabular}

開口時 患側

\begin{tabular}{r|r|r|r|r}
\hline 後 & - & 0 & + & 計 \\
\hline- & 5 & 9 & 12 & 26 \\
0 & 0 & 1 & 4 & 5 \\
+ & 0 & 0 & 2 & 2 \\
\hline 前 & \multicolumn{1}{|c|}{5} & 10 & 18 & 33 \\
\hline
\end{tabular}

\begin{tabular}{c|c|c|c|c} 
閉口時 & \multicolumn{3}{|l}{ 健側 } \\
\hline 前 & - & 0 & + & 計 \\
\hline- & 1 & 1 & 0 & 2 \\
0 & 2 & 5 & 1 & 8 \\
+ & 1 & 0 & 2 & 3 \\
\hline 計 & 4 & 6 & 3 & 13 \\
\hline
\end{tabular}

開口時 健側

\begin{tabular}{|c|c|c|c|c|}
\hline 前 & - & 0 & + & 計 \\
\hline- & 1 & 4 & 3 & 8 \\
\hline 0 & 1 & 1 & 1 & 3 \\
\hline+ & 0 & 0 & 2 & 2 \\
\hline 計 & 2 & 5 & 6 & 13 \\
\hline
\end{tabular}

\section{対象および研究方法}

対象は，昭和53年 1 月から昭和 58 年 12 月までの過去 6 年間に, 九州大学歯学部附属病院口腔外科を受診した下 顎骨骨折患者で，治療前後に Schüller 氏変法撮影を行 った症例である。このうちで, 開, 閉口時のX線像にお いて外耳孔, 関節䆚, 関節結節, および下買頭など顎関 節部周囲のトレースが可能で, さらに, 治療前と開口訓 練などの治療後訓練がある程度経過した治療後 1〜3か 月経過時の, 両者のX線像が得られた 87 症例を検索対象
とした。今回の対象87症例は，検索期間中の全下顎骨骨 折症例の約 $21.9 \%$ に相当し, 男性59症例, 女性 28 症例, 年齢分布は 6 歳から76歳までであった。

対象 87 症例について, Madsen $ら^{4,5)}$ に準じて, 開・ 閉口時における下顎頭の前後的位置関係を各々 3 群に分 類した（図1）.

\section{1. 閉口時における下顎頭の位置の分類}

(1) 後方位 (一)

下顎頭が窩内後方に位置するもの

(2) 中央位 (0)

下顎頭が裔内中央に位置するもの

(3) 前方位 $(+)$

下顎頭が裔内前方に位㯰するもの

\section{2. 開口時における下顎頭の位置の分類}

(1) 後方位 (一)

下顎頭が関節結節より後方に位置するもの(召内位)

(2) 中央位 (0)

下顎頭が関節結節の直下に位置するもの

(3) 前方位 $(t)$

下顎頭が関節結節より前方に位置するもの(㸗外位) 骨折部位別，観血的および非観血的整復による治療内 容別の治療前後における下買頭の位置変化を観察・分類 するとともに, 開口度, 頢運動, 買関節部疼痛および雑 音, 治療後の総合評価など臨床的事項との関係について 検索を行った。

なお，撮影条件などに関しては，著者の竹之下ら ${ }^{5) か ゙ ~}$ すでに顎関節症の Schüller 氏変法撮影による観察で報 告したものと同様である. 
表 2 㴿関節部骨折例の下顎頭の治療前後に怙ける 位置 (側)

\begin{tabular}{|c|c|c|c|c|}
\hline 前 後 & - & 0 & + & \\
\hline- & 3 & 1 & 1 & 5 \\
\hline 0 & 2 & 8 & 5 & 15 \\
\hline+ & 1 & 7 & 4 & 12 \\
\hline 計 & 6 & 16 & 10 & 32 \\
\hline
\end{tabular}

開口時 患側

\begin{tabular}{c|r|r|r|r}
\hline 後 & - & 0 & + & 計 \\
\hline- & 3 & 12 & 11 & 26 \\
0 & 0 & 1 & 3 & 4 \\
+ & 0 & 0 & 2 & 2 \\
\hline 計 & 3 & 13 & 16 & 32 \\
\hline
\end{tabular}

結

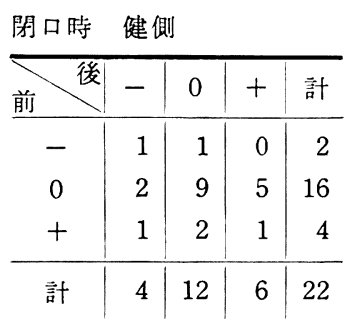

\begin{tabular}{r|r|r|r|r}
\hline 開口時 健㑡 \\
\hline 前 後 & - & 0 & + & \multicolumn{1}{l}{} \\
\hline- & 2 & 8 & 6 & 16 \\
0 & 0 & 0 & 5 & 5 \\
+ & 0 & 0 & 1 & 1 \\
\hline 計 & 2 & 8 & 12 & 22 \\
\hline
\end{tabular}

\section{1. 骨折部位別による下顎頭の位置変化}

\section{1) 骨体部骨折群}

骨体部骨折のみの症例23例では, 閉口時における下罘 頭の位置は，治療前 - 後ともに患側 $\left(\chi^{2}=0.878<\chi^{2}(2\right.$, $0.05)=5.991)$ および健側 $\left(\chi^{2}=0.476<\chi^{2}(2,0.05)=\right.$ 5.991) のいずれも中央位に多くみられ，下䫇頭の位置 分布に差異は認められなかった。開口時における下顓頭 の位置は，患側で治療前は後方位に多くみられたもの の，治療後では中央位および前方位への移行がみられ $\left(\chi^{2}=28.693>\chi^{2}(2,0.05)=5.991\right)$, 健側でも同様の傾 向を示し $\left(\chi^{2}=6.100>\chi^{2}(2,0.05)=5.991\right)$ 治療前・ 後で位置分布に有意な差異が認められた（表 1 ）.

\section{2 ) 罘関節突起部骨折群}

顎関節突起部骨折のみの症例27例では, 閉口時におけ る下顎頭の位置は, 治療前・後ともに患側で中央位, 前 方位が多く $\left(\chi^{2}=0.305<\chi^{2}(2,0.05)=5.991\right)$, 健側で 中央位に多く $\left(\chi^{2}=1.638<\chi^{2}(2,0.05)=5.991\right)$ みられ るものの, 下顎頭の位置分布に差異は認められなかった。 開口時は患側で治療前に後方位に多くみられた下䫇頭の 位置は, 治療後に中央位, 前方位へと移行し $\left(\chi^{2}=33.895\right.$ $\left.>\chi^{2}(2,0.05)=5.991\right)$, 健側でも同様の移行を呈し $\left(\chi^{2}\right.$ $\left.=11.000>\chi^{2}(2,0.05)=5.991\right)$ 治療前・後で有意な位 置分布の差異が認められた（表 2 ).

\section{3) 骨体部十䫇関節突起部骨折群}

骨体部および顎関節突起部骨折を併発した群37症例で は, 閉口時における下媔頭の位置は, 患側で治療前に中 央位, 前方位に多く, 治療後では中央位に多く $\left(\chi^{2}=\right.$

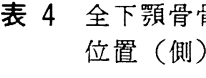

閉口時 患側

\begin{tabular}{c|r|r|r|r|r}
\hline 前 後 & - & 0 & + & 計 \\
\hline- & 9 & 8 & 3 & 20 \\
0 & 8 & 39 & 9 & 56 \\
+ & 4 & 22 & 13 & 39 \\
\hline 計 & 21 & 69 & 25 & 115 \\
\hline
\end{tabular}

開口時 患㑡

\begin{tabular}{r|r|r|r|r}
\hline 後 & - & 0 & + & 計 \\
\hline 前 & 12 & 38 & 44 & 94 \\
0 & 1 & 4 & 10 & 15 \\
+ & 0 & 1 & 5 & 6 \\
\hline 計 & 13 & 43 & 59 & 115 \\
\hline
\end{tabular}

\begin{tabular}{|c|c|c|c|c|}
\hline 前 後 & - & 0 & + & 計 \\
\hline- & 1 & 1 & 1 & 3 \\
\hline 0 & 1 & 12 & 4 & 17 \\
\hline+ & 1 & 2 & 1 & 4 \\
\hline 計 & 3 & 15 & 6 & 24 \\
\hline
\end{tabular}

開口時 健側

\begin{tabular}{r|r|r|r|r}
\hline 前 & - & 0 & + & 計 \\
\hline- & 2 & 7 & 11 & 20 \\
0 & 1 & 1 & 1 & 3 \\
+ & 0 & 0 & 1 & 1 \\
\hline 計 & 3 & 8 & 13 & 24 \\
\hline
\end{tabular}

表 3 骨体部十顎関節部骨折例の下顎頭の治療前後
閉口時 患側

\begin{tabular}{r|r|r|r|r}
\hline 前 & - & 0 & + & 計 \\
\hline- & 4 & 17 & 21 & 42 \\
0 & 1 & 2 & 3 & 6 \\
+ & 0 & 1 & 1 & 2 \\
\hline 計 & 5 & 20 & 25 & 50 \\
\hline
\end{tabular}

\begin{tabular}{r|r|r|r|r}
\hline 前 後 & - & 0 & + & 計 \\
\hline- & 4 & 5 & 1 & 10 \\
0 & 3 & 16 & 2 & 21 \\
+ & 2 & 10 & 7 & 19 \\
\hline 計 & 9 & 31 & 10 & 50 \\
\hline
\end{tabular}

開口時 患㑡 $\left.4.769<\chi^{2}(2,0.05)=5.991\right)$ みられ, 健側では治療前・ 後とも中央位に多く又られるものの, 下顎頭の位置分布 に差異は認められなかった。開口時患側では, 治療前に 後方位に多くみられた下買頭の位置は，治療後では中央 位, 前方位に多く又られ $\left(\chi^{2}=56.259>\chi^{2}(2,0.05)=\right.$ $5.991)$, 健側でも同様の傾向を示し $\left(\chi^{2}=25.124>\chi^{2}\right.$ $(2,0.05)=5.991)$ 治療前・後で位置分布に有意な差異 が認められた（表了）.

4) 全下顎骨骨折

下顎骨骨折全例 87 症例についてみても上記各骨折群之 同様の傾向を呈し，治療前後の下顎頭の位置は，閉口時 には患側 $\left(\chi^{2}=4.439<\chi^{2}(2,0.05)=5.991\right)$, 健側 $\left(\chi^{2}\right.$ 
表 5 観血的処置前後の下顎頭の位置（側） 閉口時 患㑡

\begin{tabular}{c|r|r|r|r|r}
\hline 後 & - & 0 & + & 計 \\
\hline- & 5 & 5 & 2 & 12 \\
0 & 4 & 20 & 5 & 29 \\
+ & 3 & 12 & 7 & 22 \\
\hline 計 & 12 & 37 & 14 & 63 \\
\hline
\end{tabular}

開口時 患側

\begin{tabular}{r|r|r|r|r}
\hline 後 & - & 0 & + & 計 \\
\hline 前 & 7 & 22 & 24 & 53 \\
0 & 1 & 2 & 4 & 7 \\
+ & 0 & 1 & 2 & 3 \\
\hline 計 & 8 & 25 & 30 & 63 \\
\hline
\end{tabular}
閉口時 健側

\begin{tabular}{r|r|r|r|r}
\hline 後 & - & 0 & + & 計 \\
\hline- & 2 & 2 & 1 & 5 \\
0 & 3 & 11 & 5 & 19 \\
+ & 2 & 3 & 2 & 7 \\
\hline 前 & 7 & 16 & 8 & 31
\end{tabular}

表 6 非観血的処置前後の下顎頭の位置（側） 閉口時 患側

\begin{tabular}{r|r|r|r|r}
\hline 後 & - & 0 & + & 計 \\
\hline- & 4 & 3 & 1 & 8 \\
0 & 4 & 19 & 4 & 27 \\
+ & 1 & 10 & 6 & 17 \\
\hline 前 & 9 & 32 & 11 & 52 \\
\hline
\end{tabular}

開口時 患側

\begin{tabular}{c|r|r|r|r}
\hline 後 & - & 0 & + & 計 \\
\hline- & 5 & 16 & 20 & 41 \\
0 & 0 & 2 & 6 & 8 \\
+ & 0 & 0 & 3 & 3 \\
\hline 計 & 5 & 18 & 29 & 52
\end{tabular}
閉口時 健側

\begin{tabular}{r|r|r|r|r}
\hline 後 & - & 0 & + & 計 \\
\hline- & 1 & 1 & 0 & 2 \\
0 & 2 & 15 & 5 & 22 \\
+ & 1 & 1 & 2 & 4 \\
\hline 前 & 4 & 17 & 7 & 28 \\
\hline
\end{tabular}

\begin{tabular}{r|r|r|r|r}
\hline 開口時 & \multicolumn{3}{|l}{ 健側 } \\
\hline 前 & - & 0 & + & 計 \\
\hline- & 3 & 9 & 10 & 22 \\
0 & 1 & 1 & 3 & 5 \\
+ & 0 & 0 & 1 & 1 \\
\hline 計 & 4 & 10 & 14 & 28
\end{tabular}

$\left.=2.369<\chi^{2}(2,0.05)=5.991\right)$ とも位置分布の変化に差 異が認められないものの, 開口時には患側 $\left(\chi^{2}=118.050\right.$ $\left.>\chi^{2}(2,0.05)=5.991\right)$, 健側 $\left(\chi^{2}=50.797>\chi^{2}(2,0.05)\right.$ $=5.991)$, いずれも有意な位置分布の変化が認められた (表 4)

\section{2. 処置内容別による下顎頭の位置变化}

下顎骨骨折後の処置として, 観血的処置群と非観血的 処置群に分類し, 各処置群について治療前後の下䫁頭の 位置変化をみると以下のごとくであった（表 5，6）.

推血的処置群は，閉口時には患側 $\left(\chi^{2}=2.747<\chi^{2}(2\right.$, $0.05)=5.991)$, 健側 $\left(\chi^{2}=0.657<\chi^{2}(2,0.05)=5.991\right)$ ともに治療前・後で下靧頭の位置分布に変化は認められ なかったが，開口時に患側 $\left(\chi^{2}=43.322>\chi^{2}(2,0.05)=\right.$ $5.991)$, 健側 $\left(\chi^{2}=25.711>\chi^{2}(2,0.05)=5.991\right)$ いず
表 7 臨床症状変化（I）

開口度変化（例）

\begin{tabular}{c|c|r|r|r|r}
\hline 前 & I & II & III & IV & 計 \\
\hline I & 0 & 1 & 18 & 10 & 29 \\
II & 0 & 2 & 24 & 25 & 51 \\
II & 0 & 0 & 2 & 5 & 7 \\
IV & 0 & 0 & 0 & 0 & 0 \\
\hline 計 & 0 & 3 & 44 & 40 & 87 \\
\hline
\end{tabular}

I. 開口度 $\sim 15 \mathrm{~mm}$ (1 Q.F.B. 未满)

II. 開口度 $16 \sim 30 \mathrm{~mm}(1 \sim 2$ Q.F.B. $)$

III. 開口度 $31 \sim 45 \mathrm{~mm}(2 \sim 3$ Q.F.B. $)$

IV. 開口度 45〜 $\mathrm{mm}$ (3 Q.F.B. 以上)

顎運動変化（例）

\begin{tabular}{c|c|c|c}
\hline 後 & $\begin{array}{c}\text { 顎運動時 } \\
\text { 偏位 }(+)\end{array}$ & $\begin{array}{c}\text { 顎運動時 } \\
\text { 偏位 }(-)\end{array}$ & 計 \\
\hline $\begin{array}{c}\text { 前 } \\
\text { 顎運動時 }\end{array}$ & 4 & 75 & 79 \\
$\begin{array}{c}\text { 顎運動時 } \\
\text { 偏位 }(-)\end{array}$ & 0 & 8 & 8 \\
\hline 計 & 4 & 83 & 87 \\
\hline
\end{tabular}

れも治療前後で有意な下顎頭の位置分布の変化が認めら れた。

非観血的処置群でも，閉口時患側 $\left(\chi^{2}=1.768<\chi^{2}(2\right.$, $0.05)=5.991)$ ， 健側 $\left(\chi^{2}=2.126<\chi^{2}(2,0.05)=5.991\right)$ および開口時患側 $\left(\chi^{2}=53.145>\chi^{2}(2,0.05)=5.991\right)$ ， 健側 $\left(\chi^{2}=25.395>\chi^{2}(2,0.05)=5.991\right)$ いずれも観血 的処置群と同様の傾向を呈し，治療前後で閉口時には下 顎頭の位置分布に変化は認められないものの，開口時に は位置分布に有意な変化が認められた。

\section{3. 治療前後における臨床症状の变化}

1）開口度および㖽運動変化

開口度について表 7 のごとく 4 段階に分類してみる と, 治療前では I : 29例, II : 51例と 2 横指未満の開口 度を呈した症例が計80例 (91.9\%) であったのに対し, 治療後では逆に III:44例， IV : 40例と計84例 (96.6\%) で 2 横指以上の開口が可能で有意な開口度の上昇が認め られた。顎運動変化では，治療前に79例 (90.8\%) に認 められた顓運動の 異常は, 治療後 4 例 (4.6\%) にみら れたのみで顕著な改善が認められた。ささらに，治療前後 を通じて䫇運動の異常を示さなかった症例が8例 (9.2 \%)であった（表 7).

2）顎関節部症状変化

罘運動時に顎関節部に疼痛のあった症例が治療前80例 (92.0\%) であったのに対し，治療後では6 例 (6.9\%) と減少しており, 残りの 7 例 $(8.0 \%)$ は治療前後を通じ て疼痛は認められなかった。治療前 9 例 $(10.3 \%$ ) に認 
表 8 臨床症状変化（II）

顎関節部疼痛変化（例）

\begin{tabular}{c|c|c|c}
\hline 前 & 疼痛 $(+)$ & 疼痛 $(-)$ & 計 \\
\hline 疼痛(+) & 6 & 74 & 80 \\
疼痛(一) & 0 & 7 & 7 \\
\hline 計 & 6 & 81 & 87 \\
\hline
\end{tabular}

顎関節部雑音変化（例）

\begin{tabular}{|c|c|c|c|}
\hline 前 後 & 雑音 $(+)$ & 雑音 (一) & 計 \\
\hline 雑音(十) & 2 & 7 & 9 \\
\hline 雑音(） & 1 & 77 & 78 \\
\hline 計 & 3 & 84 & 87 \\
\hline
\end{tabular}

められた買関節部雑音は，治療後は治療前後ともにみら れた 2 例と治療後新たに生じた 1 例の計 3 例 (3.4\%)に みられたが，77例（88.5\%）で治療前後を通じて認めら れなかった（表 8 ).

\section{3）下顎骨骨折治療後の総合評価}

下顎骨骨折治療後の総合評価について，顎関節部の評 価ではあるが中富 ${ }^{6)}$ に準じて分類を行った．上記分類に より症例87例についての治療後評価を行ってみると，表 9 に示すごとく完全治㾭 I（開口度：3 Q.F.B.または それ以上）: 34 例，完全治瘉 II（開口度：3 Q.F.B.未 満)：42 例と計 76 例 $(87.4 \%$ ) で治痹良好と判断され, また日常生活に不自由を感じない障害 I：7 例を含める と83例（95.4\%）について良好な治嘴状態が認められた (表 9 ).

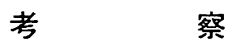

近年，とみに複雑な社会環境を反映して，靧・顔面骨 骨折患者は経年的に增加の傾向を示しており，そのうち で最も頻度が高い下顎骨骨折症例についても多くの臨床 統計的観察が報告されている

下顎骨骨折患者の診断および治療，さらには経過観察 などにおいては種々のX線学的検査法が用いられてい る.下顎頭の位置や動きの観察には，X線テレビ映画 ${ }^{14)}$, パントモグラム ${ }^{15,16)}$ ，斜方向規格像 ${ }^{17)}$ などよる評価も 行われているが，当科においては Schüller 氏法に準じ た撮影法による開・閉口位での 2 回撮影像を用いてい る.今回観察を行った同撮影法によるX線像は钽密な意 味での規格化像ではないが，臨床的にはかなり有効であ $ろ^{5,18)}$.

今问の観察では，閉口位における下顎頭の位置は，下 顎骨骨折部位別，処置内容別にかかわらず治療前・後で 患・健側いすれれ中央位の占める割合が多く，処置によ
表 9 下顎骨骨折治療後の総合評価

\begin{tabular}{|c|c|}
\hline 評＼cjkstart価 & 治療後 $1 \sim 3$ 月経過時 \\
\hline 完全治痰 I & 34 例 $(39.1 \%)$ \\
\hline 完全治瘾 II & 42 例 $(48.3 \%)$ \\
\hline 障 害 I & 7 例 $(8.0 \%)$ \\
\hline 障 害 & 4 例 $(4.6 \%)$ \\
\hline 障 害 & 0 例 ( $0 \%)$ \\
\hline 計 & 87 例 ( $100 \%)$ \\
\hline
\end{tabular}

る位置変化は認められなかった。下顎骨骨折例での報 告ではないが，他家の文献との比較を試みた。まず， Madsen ${ }^{4)}$ の顎関節部に病的症状を有しない群での報告 によると，後方位 30 , 中央位 135 , 前方位 27 であり, 今 回の結果と比較してみると患側, 健側, さらには本症例 の両側合計，いずれも閉口位における下顎頭の位置分布 に差はみられないようである。ささらに，竹之下らうの顎 関節症症例における健常側79側では，後方位13，中央位 53，前方位 13 であり，同様に分布差は認められず，川 瀬 ${ }^{3}$ の顎関節に異常のない対照群 40側の位置分布ともか なり一致していた。 Weinberg ${ }^{19)}$ は，顎関節部症状群と 対照群との比較により，閉口位における下顎位には差が ないと述べているが，今回の検討でも，竹之下ら の顎 関節症状群 176 側と比較しても下㴿位の分布に差は認め られなかった。

下顎骨骨折症例においては，観血的あるいは非観血的 に処置を施行するとしても，咬合整復後に固定を行うけ れども, 閉口位における下買位の分布に治療前・後, さ らには患・健側間で差がみられなかったことから，関節 裔内に拈ける下顎頭の位置は処置によってさ汪影響を 受けないようである.

開口位における観察では，骨折部位別，処置内容別い ずれも治療前・後で下顎頭の移行が認められ，治療前に は患側で約 $78 \%$ 以上，健側で約 $61 \%$ 以上を後方位が占め ていたのに対し，治療後では患側で約 $13 \%$ 以下，健側 で約 $15 \%$ 以下に顕著に減少し，中央位および前方位への 移行がみられた。開口位における下顎頭の位置変化は， 治療前の外偟ないし骨折に伴う疼痛および機能障害によ る開口障害をきたしていたものが，骨折治療後の疼痛お よび機能障害の減少による開口状態の改善に起因するも のと考えられる。

開口位における下靧頭の位置分布では，Madsen'は， 顎関節部に病的症状を有しない群で, 後方位 70 , 中央位 12 ，前方位 104 であり，竹之下らうは，䫇関節症の健側 で，後方位 33 , 中央位 12 , 前方位 34 と, 後方位および前 方位の割合が多いとしているが，今回の検討では，治療 後，患・健側ともに中央位势よび前方位の割合が多く両 
者で約 $90 \%$ 近くを占めていた，罰関節症状を有する群 では, 竹之下 $5^{5)}$ は後方位 48 , 中央位 10 , 前方位 21 て $35.7 \%$ が前方位にあったとし, Markovic $5^{20)}$ も100例中 32例が関節結節を越えていたと報告している，開口位に おける下靧頭の位置は，治療前・後ともに患側・健側い ずれも類似の分布比率を示し，とくに治療後では患側の 運動障害と，健側の代償的運動障害を示唆するX線像が 認められる一方，特別な症状を呈さず，治療後の顎の機 能的回復がなされているようである.

下靧骨骨折に批いては，咀嚼笳群の作用に伴い骨折部 位により骨片の転位を起こすとともに，異常状態による 疼痛と罘機能障害を呈する，通常では下罰頭は，最大開 口時に滑走運動により関節結節を越えて移動することが 知られている ${ }^{21)}$ が，これが制限されて前方位まで達しな くなることにより，開口障害をはじめとした顎運動機能 障害を呈してくる，上條22)によれば，最大開口時に正常 者でも下靧頭が関節結節を越えて前斜面の半分以上に達 するものが38\%，前斜面の半分以下に達するものか333\% で計71\%に前方位がみられるとし，Laskin ${ }^{23}$ は，正常者 でも関節結節の前方 $5 \mathrm{~mm}$ まで移動すると述べており， Ricketts ${ }^{24)}$ は，下買頭中心の下方に下顎頭の回転中心 を定めると, 前方運動時に正常者で関節結節の後方 5 $\mathrm{mm}$ から前方 $8 \mathrm{~mm}$ までに下顎頭の移動がみられると 報告している.

今回の観察では, 治療前に㧊りる開口度 $30 \mathrm{~mm}$ 未満 の症例は 80 例 $(92.0 \%)$ と大部分を占め, 174 側中 138 側 （79.3\%）が後方位であったのに対し，治療後は開口度 の上昇とともに，逆に開口度 $30 \mathrm{~mm}$ 以上の症例が84例 (96.5\%) と增加し，174側中90側 $(51.7 \%)$ か関節結節 を越えて前方位にあり，X線学的にも䫇運動機能の回復 が認められた。

山野 ${ }^{15)}$ は， 20〜30 mm の開口状態まで下靧頭は関節

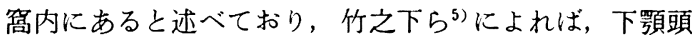
が関節結節直上にくるのは開口度が約 $30.8 \mathrm{~mm}$ のとこ ろであり，Eckelt ${ }^{25)}$ は，下靧頭が関節結節まで移動す るのに $30 \mathrm{~mm}$ 以上の開口が必要だと報告している.

Sheppard $5^{26)}$ は，顎関節症状を呈さない症例の開口位 においては $80 \%$ 以上に下頱頭の位置が関節結節の直上ま たは前方位にみられたと報告しており，著者らの観察に おける治療後の下顎頭の位置分布とほぼ同様の傾向を示 していた。開口制限の一般的基準として，中村 ${ }^{27)}$ は開口 度 $30 \mathrm{~mm}$ ，竹之下ら ${ }^{5)}$ は同 $35 \mathrm{~mm}$ 前後を目安とすると 述べているが，今回の観察でも開口度 $30 \mathrm{~mm}$ 未満 (I および II）の症例では開口位で下頡頭が関節召内にとど まって後方位を呈している割合が多く，骨折治療後の開 口訓練においても，関節結節直上あるいは関節結節を越 えて前方位へ移動する境界值として開口度 $30 \sim 35 \mathrm{~mm}$ を目標とすることは妥当なことと考えられた，

顎運動機能障害について, 岡ら ${ }^{11}$ は骨折以外にも軟部
損賃による二次的継発的障害として成立寸る場合も考え られ，運動機能の予後評価にあたっては開口運動障害， さらには側方運動障害の有無も無視し得ない要素だと述 べている。このよ5に, 口角部や頓部などの軟組織欠 損, 般痕による開口障害や側方運動障害が生じることも あるが，今回はそのよらな症例はみられなかった。開口 位における顎偏位の有無について調査を行ったところ，

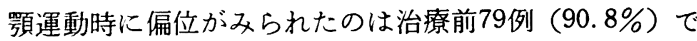
あったのに対し，治療後は 4 例 $(4.6 \%)$ に認められた のみであった，治療前に顎運動時に偏位が認められた79 例のらち，左右における下顎頭の位置が異なっているも のは, 閉口位で39例 $(49.4 \%)$, 開口位で65例 $(82.3 \%)$ であった，治療後に堮頁運動時の偏位が消失した 75 例で は, 閉口位で 10 例 $(13.3 \%)$, 開口位で 21 例 $(28.0 \%)$ にX線上で下顎頭の位置の異なるものがみられた。 Updegrave ${ }^{28)}$ はX線に批観察で，90例中68例（75.6 \%）に左右の機能的一致がみられたと報告しているが, 今回の観察でも治療後の㴿運動機能の回復に伴い, 機能 的に両側の下顎頭が全く相同の動きをしているといら訳 ではないが，機能的一致度は上昇し，症状からみて機能 上とくに問題はなく，左右の下靧頭位がよしんば異なる としても，ある程度の相補的協調関釈が生しているもの と思われた。

治療前・後で顎関節部疼痛が認められたのは, 顎関節 突起部骨折 1 例 (片側性), 骨体部十顎関節突起部骨折 5 例（両側性 3 例, 片側性 2 例) の計 6 例 (6.9\%) で, いずれも罘関節部の骨折症例であった。下顎頭の位直 は，閉口位では治療前・後で特異的変化は認められない ものの, 開口位では治療前・後で疼痛が認められなかっ た 7 例 (8.0\%) に後方位がみられなかったのに対し, 疼 痛が認められた 6 例では治療後も後方位の占める割合が 多く，開口制限を伴っていた，さらに，6 例のうち左右 における下顎頭位が一致していたのは，開口位で治療前 1 例，治療後 2 例であり，不一致の割合が多いようであ る.

治療前に顎関節部雑音が認められた 9 例 $(10.3 \%)$ で は，閉口位は患側で各下靧位がそれぞれ約 $1 / 3$ ずつを占 めていたのに対し，健側では中央位が多数を占めていた が関節窩内に扣ける下願頭の位置に特異的変化は認めら れず，さらに開口位では，患・健側いずれも後方位が多 数を占めており, 治療前では関節窝内に拈ける発生が示 唆されるよらである，治療後では，治療前後を通して認 められた 2 例と治療後新たに生じた 1 例の計 3 例（3.4 \%) に雑音が認められ，それらは顎関節部骨折 1 例，骨 体部十靧関節突起部骨折 2 例であり，罘関節部疼痛群と 同様にいずれも顎関節部の骨折症例であった。 3 例にお ける下顎頭の位置は, 閉口位患側は治療前・後いずれも 後方位 2 例, 中央位 1 例であり, 開口位患側では治療前 に後方位 3 例, 治療後に中央位 2 例, 前方位 1 例が認め 
られた。さらに顎関節部疼痛と雑音の重複する症例が 2 例みられたが，治療前・後ともに患側の下顎頭の位置は 開・閉口位のいすれれ後方位に認められ，左右における 下顎位は異なっていた。今回は症例が少ないため，一定

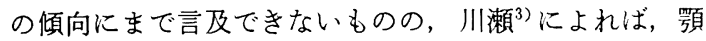
関節部疾患群と対照群との比較により, 前者の閉口位に おける下顎頭の位置は前方位または後方位にあるものが 多い傾向にあり，開口位においては雑音を訴える症例で は正常者とほぼ同様の下顎位であるが，疼痛を訴える症 例では関節窩外のものが少なく, 症状発作位の下顎頭は 患側で関節窩前壁部付近にあり，健側では関節窩前壁付 近または関節裔外にあると報告している。

中富 ${ }^{6}$ の分類に準した治療後の総合評価において76例 (87.4\%) に治癒良好が示され，障害が残っていると判 断された11例 $(12.6 \%)$ では顎関節部骨折を含む症例が 9 例と多くみられるものの，閉口位における下顎頭の位 置分布に治癒良好群との差異は認められなかった。開口 位においては，治療前に患・健側の両側 (22側) で後方 位が21側 (95.5\%) と大部分を占めており，治療後でも 後方位 10 側 $(45.4 \%)$, 中央位 8 側 $(36.4 \%)$, 前方位 4 側 $(18.2 \%)$ と後方位の占める割合が多く認められた。 これは対象の顎間固定解除後の期間なども反映している と思われるが，なお開口障害の成立がうかがえる。

顎骨骨折では早期に適切な治療がなされ，一定期間の 固定が確実になされ，治療後の機能訓練が十分であれば 顎機能の回復は良好とされている。しかしながら，受傷 年齢，受傷より処置開始までの期間，骨折部位，さらに は処置方法などその予後を左右する因子は複雑であり後 遺症についての文献も多い6,7,10,11,29,30). 今回は治療後 1 〜 か月経過時における観察であったが，さらに長期 にわたる経過観察でも開口度はさほど急激に增加しない にしても，顎関節部の愁訴は漸次减少傾向にある症例も 多く，下䫇頭と関節窩および関節結節との多様性にもか かわらず，経過とともに機能的には影著な改善傾向を示 し，さほど障害を残さないこと，つまり外側翼突筋をは じめとした咀嚼筋群の協調ならびに機能的適合が生じて いるものと思われた。

\section{結論}

下顎骨骨折の治療前後に Schüller 氏変法撮影による 顎関節部の X線診査を行った 87 症例について検討を加 え，以下のような結論を得た。

1. 骨体部骨折, 嶺関節突起部骨折, 骨体部十顎関節 突起部骨折，扣よび全下顎骨骨折のいずれの群において も, 閉口位における患・健側の治療前後の関節窩におけ る下顎頭の位置分布に変化はみられなかった。

また，各骨折分類別ならびに全下㴿骨骨折のいずれの 場合でも，開口位における患・健側の治療前後の比較て
は，下顎頭の位置は関節結節の前方位が有意に增加して いた。さらに，観血的ならびに非観血的処置のい寸゙れの 場合においても，上記の傾向が少られ，両処置間で特異 的差異は認められなかった。

2. 帰属的評価では，治療前に大部分の症例で開口度 は $30 \mathrm{~mm}$ 末满であったが，治療後では $30 \mathrm{~mm}$ 以上の 開口度を示していた。治療後において，頻運動時の偏位 は有意に減少し，顎関節部の疼痛も著明な減少を示し， 雑音に関しても少数ながらも減少傾向がみられた。治療 後 $1 \sim 3$ か月経過時の総合評価において，約 $87 \%$ に治癒 良好が得られた。

3. 下顎骨骨折における治療前後の下顎頭の位置は総 体として多様性を示し，乙かも閉口位における治療前後 の位置変化はみられず，機能的障害と下顎頭の位置との 関係は見い出せなかった。治療後の評価において，顎運 動機能は十分回復しており，したがって機能的適合が生 じているものと思われた。

本論文の要旨は，昭和59年 5 月18日第38回日本口腔科 学会総会（於，東京都）にて発表した。

\section{引用 文 献}

1) Hankey, G.T.: Temporomandibular arthrosis, an analysis of 150 cases. Br Dent J 157: 2492701954.

2) Mikheil, M.G. and Rosen, H.: The validity of temporomadibular joint radiographs using the head positioner. J Prosth Dent 42: 4414461979 .

3）川瀬充朗：䫍関節症患者の咬合力に関する研究 一開口域および顆頭位との関連一。補経誌 14 : 51-72 1970.

4) Madsen, B.: Normal variations in anatomy, condylar movement and arthrosis frequency of the temporomandibular joints. Acta Radiol 4: 273-288 1966.

5) 竹之下康治, 中村昭一, 他 : 䫇関節症のSchüller 氏変法X線像に上る钼察。日口外誌 27：5655721981.

6) 中富鼃次郎：顎関節突起骨折の臨床的研究. 口 科誌 13：132-156 1964 .

7）田代英雄, 納富一幸, 他：下罘関節突起基部骨 折の钼血的治潦についての検討 (抄). 日口外 誌 20:743 1974 .

8）竹之下康治，納富一幸，他：顎骨を中心とする 顔面骨骨折様相の推移。口科誌 31: 407-418 1982.

9）鉿木和彦，三宅久実男，他：過去 12 年間当教室 に扣ける顎顔面骨骨折の臨床統計的䘽察。日口 外誌 24: 1084-1090 1978 .

10）井上靖彦，石黑 光，他：過去 10 年間の顎骨骨 折の臨床統計的観察とその遠隔成績。日口外誌 
22: 855-859 1976.

11）岡達, 金田敏郎, 他: 下顎関節突起骨折の 予後に関する研究. 日口外誌 22：793-800 1976.

12）清田健司：小児顎骨骨折に関する臨床的ならび にX線学的研究。口病誌 43：479-508 1976.

13) 久保四郎, 村橋 護, 他: 顎関節突起骨折 124 症例に関する臨床的検討，特にその分類につい て。 日口外誌 29：1794-1805 1983.

14）大森明彦：X線テレビ映画法による下顎頭の運 動変化について.料学報 79: 1661-1677 1979.

15）山野博可：顎関節運動のパントモグラムによる 解析. 日大釈学 40: 32-53 1966.

16) 北本 厚, 高岡 茂, 他：パントモグラムによ る下顎頭の移動パターンの検討. 日大口腔科学 6: 110-114 1980 .

17）青島 攻：側斜方向X線規格像による顎運動 （前方運動，後方運動）の解析. 日大菌学 48: 519-533 1974.

18）竹之下康治, 中村昭一, 他：顎関節脱臼の $\mathrm{X}$ 線 学的観察. 日口外誌 28：222-230 1982.

19) Weinberg, L.A.: An evaluation of asymmetry in TMJ radiographs. J Prosthet Dent 40: 315-323 1978.

20) Markovic, M.A. and Rosenberg, H.M.: Tomographic evaluation of 100 patients with temporomandibular joint symptoms. Oral Surg 42: 838-846 1976.

21）柳沢定勝：罘関節のレントゲン学的研究. 歯科 月報 34：471-497 1960 。
22）上條雍彦：䪽関節について。国際菌科ジーーナ ル 5: 389-396 1977.

23) Laskin, D.M.: Surgery of the temporomandibular joint. In Temporomandibular Joint Problems, Solberg, W.K. \& Clark, G.T. ed, Quintessence Publishing Co, Chicago, 1980, p 111.

24) Ricketts, R.M.: Variations of the temporomandibular joint as revealed by cephalometric laminagraphy. Am J Orthod 36: 877-898 1950.

25) Eckelt, U. and Pinkert, R.: Die Beurteilung der Kiefergelenkfunktion nach Kollumfrakturen anhand von Röntgen-Serien aufnahmen. Stomat DDR 24: 796-800 1974.

26) Sheppard, I.M. and Sheppard, S.M.: Subluxation of the temporomandibular joint. Oral Surg 44: 821-828 1977.

27）中村允也：顎関節症の臨床的研究. 口病誌 26 : 986-1012 1959

28) Updegrave, W.J.: Roentgenographic observations of functioning temporomandibular joints. JADA 64: 488-505 1957.

29) 石井保雄：下䫇骨骨折，顔面外傷. 外科 Mook $21 ， 1981$ ，金原出版，東京，231-248頁。

30）田代英雄，納富一幸：下顎関節突起基部骨折の Kirschner 鋼線による固定. 形成外科 22：36421979. 